J. Clin. Chem. Clin. Biochem.

Vol. 18, 1980, pp. 287-291

\title{
Urinary Excretion of Collagen Metabolites in Protein Malnutrition ${ }^{1}$ )
}

By J. Sambasiva Rao and V. H. Rao

Department of Biochemistry, Central Leather
Research Institute, Madras, India ..

Received August 21, 1979 / January 2, 1980)

Summary: The effect of protein deficiency on the urinary excretion of hydroxyproline (total, nondialysable, dialysable and free fractions) and hydroxylysyl glycosides (glucosyl-galactosyl-hydroxylysine, glc-gal-hyl and galactosyl-hydroxylysine, gal-hyl) was investigated in female albino rats. In comparison to controls, the protein deficient animals were found to excrete significantly decreased amounts of urinary hydroxyproline fractions from the 7th day onwards. The excretion of total hydroxylysyl glycosides in urine parallels the excretion of hydroxyproline. The urinary output of both glc-gal-hyl and gal-hyl was also appreciably lower in deficient animals. The normal ratio of glc-gal-hyl/gal-hyl found in the urine of protein deficient animals suggests that there is a similar decreased turnover of collagen in both bone and skin.

\section{Ausscheidung von Kollagen-Metaboliten im Harn bei Protein-Mangelernährung}

Zusammenfassung: Die Wirkung eines Proteinmangels auf die Ausscheidung von Hydroxyprolin (gesamtes, nicht dialysierbares, dialysierbares und frejes) und Hydroxylysyl-Glykosiden (Glucosyl-galaktosyl-hydroxyly sin, Glc-GalHyl und Galaktosyl-hydroxylysin, Gel-Hyl) im Harn wurde an weiblichen Albinoratten untersucht. Im Vergleich zu den Kontrollen schieden die Tiere mit Proteinmangel vom 7. Tage an signifikant niedrigere Mengen der Hydroxyprolinfraktionen im Harn aus. Die Ausscheidung der Gesamt-Hydroxylysylglykoside im Harn verlief parallel der Ausscheidung an Hydroxyprolin. Die Ausscheidung beider Glykosidfraktionen im Harn war bei den Tieren mit Proteinmangel ebenfalls beträchtlich niedriger. Das normale Verhältnis von Glc-Gal-Hyl zu Gal-Hyl im Harn der Tiere mit Proteinmangel kann deshalb auf einen gleichermaßen verringerten Umsatz von Kollagen sowohl in Knochen als auch Haut hinweisen.

\section{Introduction}

The spectrum of protein-calorie malnutrition has presented a diagnostic problem for many years. Impaired wound healing (1) as well as decreased tensile strength of wounds (2), tail tendons and skins (3) is reported in protein malnutrition. The collagen content and its synthesis have been shown to decrease in rats fed with a protein deficient diet (4-9). Isotopic studies in this laboratory have indicated that the synthesis and catabolism of both soluble and insoluble collagen; and its maturation are decreased in protein deficient rats compared to controls (10).

As hydroxyproline is found almost exclusively in collagen, its excretion in the urine can be used to follow

\footnotetext{
1) Presented at National Symposium on Food Proteins, Madras, March 17-19, 1979.
}

the changes in the metabolism of collagen $(11,12)$. It is observed that the excretion of urinary hydroxyproline is low in both human and experimental protein-calorie malnutrition $(5,6,13-15)$. So far, no report is available on the urinary excretion of either dialysable and nondialysable hydroxyproline fractions, or hydroxylysyl glycosides in protein mulnutrition. It was therefore felt it worthwhile to study systematically the urinary excretion of hydroxylysyl glycosides and hydroxyproline fractions in protein deficient rats at weekly intervals upto four weeks.

\section{Materials and Methods}

Twenty one days old weanling female albino rats were fed with the basal diet for one week and then divided into two groups. The first group was allowed to continue with the basal diet (casein 
fraction 0.20) and served as the control; the other group was fed with low protein diet (casein fraction 0.06 ), the details of which were described previously (16). Water was supplied ad libitum and both groups were given the required vitamins. Because of a decreased food intake in the protein deficient animals (16), the control rats were pair-fed with the protein deficient animals. At weekly intervals, the body weights were recorded. During the period of urine collection, the animals received only water.

Urine samples were collected weekly for a period of $24 \mathrm{~h}$ following gastric loading with $30 \mathrm{ml} / \mathrm{kg}$ body weight of saline. The total and free hydroxyproline contents of urine were measured in hydrolysed and unhydrolysed samples by the method of Rojkind \& Gonzalez (17). The nondialy sable hydroxyproline fraction was isolated by dialysing aliquots of urine against $0.15 \mathrm{~mol} / 1$ $\mathrm{NaCl}$ and distilled water at $4{ }^{\circ} \mathrm{C}$ for $24 \mathrm{~h}(18)$ and the hydroxyproline content was determined as before. The dialy sable hydroxyproline was assessed by subtracting nondialysable hydroxyproline.from total hydroxyproline. The urinary hydroxylysyl glycosides were analysed on pooled samples by the method of Askenasi (19). Results were expressed per gram creatinine in order to account for eventual incomplete collection of urine samples (11). The creatinine was determined by the Jaffe reaction (20). The results were statistically evaluated using Student's ' $t$ ' test. The difference was regarded as significant at the level of $\mathrm{p}<0.05$.

\section{Results}

The initial mean body weight $(50 \mathrm{~g})$ of control group and its respective protein deficient group was not significantly different. The body weights of the controls increased to a mean of $88 \mathrm{~g}$ on the 28th day as compared with $67 \mathrm{~g}$ in the corresponding protein deficient group. Differences between protein deficient and control groups were significant from the 14th day onwards up to the end of the experiment $(p<0.05)$.

Table 1 shows the effect of protein malnutrition on the urinary excretion of total hydroxyproline. Compared to the control group, urinary total hydroxyproline was significantly decreased in the protein deficient animals from the 7th day onwards. It is also evident that in protein deficient animals a marked decrease in the urinary hydroxyproline occurred on the 7 th day and thereafter the decrease was gradual.

Results on the urinary excretion of nondialysable (tab. 2) and dialysable hydroxyproline (tab. 3) in protein deficient animals showed a significant decrease from the 14th day onwards up to the end of the experiment.

The urinary excretion of free hydroxyproline was also found to decrease in the deficient animals as compared to controls, but the difference was not statistically significant on the 14th day (tab. 4).

It is evident from figure 1 that the total urinary excretion of hydroxylysyl glycosides parallels that of total hydroxyproline. Compared to the controls, the deficient animals were found to excrete less total hydroxylysyl glycosides

Tab. 1. Effect of protein deficiency on the urinary excretion of total hydroxyproline ( $\mu \mathrm{mol} / \mathrm{g}$ creatinine) in the rat.

\begin{tabular}{llllll}
\hline Group & 0 & 7 & Days & 21 & 28 \\
\hline Control & $855.07 \pm 38.90^{*}$ & $896.26 \pm 45.46$ & $919.91 \pm 51.33$ & $868.04 \pm 35.16$ & $810.07 \pm 30.82$ \\
Deficient & $826.09 \pm 41.11$ & $647.60 \pm 27.38^{* *}$ & $725.40 \pm 28.99 * *$ & $623.19 \pm 24.26 * *$ & $562.17 \pm 22.43^{* *}$ \\
\hline
\end{tabular}

$*=$ Results are means $\pm \mathrm{SE}$.

$* *=$ Protein-deficient group is significantly different from control group at $p<0.05$.

Tab. 2. Effect of protein deficiency on the urinary excretion of nondialysable hydroxyproline ( $\mu$ mol/g creatinine) in the rat.

\begin{tabular}{llllll}
\hline Group & 0 & 7 & Days & \\
\hline Control & $52.86 \pm 2.52^{*}$ & $55.00 \pm 2.82$ & $53.47 \pm 2.52$ & $55.84 \pm 2.90$ & $54.77 \pm 2.67$ \\
Deficient & $55.0 \pm 2.36$ & $35.47 \pm 1.68^{* *}$ & $37.45 \pm 1.91^{* *}$ & $37.76 \pm 1.75^{* *}$ & $39.82 \pm 2.06 * *$ \\
\hline
\end{tabular}

$*=$ Results are means \pm SE.

$* *=$ Protein-deficient group is significantly different from control group at $p<0.05$.

Tab. 3. Effect of protein deficiency on the urinary excretion of dialysable hydroxyproline ( $\mu \mathrm{mol} / \mathrm{g}$ creatinine) in the rat.

\begin{tabular}{|c|c|c|c|c|c|}
\hline \multirow[b]{2}{*}{ Group } & \multirow[b]{2}{*}{0} & \multirow[b]{2}{*}{7} & \multicolumn{3}{|l|}{ Days } \\
\hline & & & 14 & 21 & 28 \\
\hline $\begin{array}{l}\text { Control } \\
\text { Deficient }\end{array}$ & $\begin{array}{l}802.21 \pm 37.50^{*} \\
771.09 \pm 34.23\end{array}$ & $\begin{array}{l}841.26 \pm 44.67 \\
612.13 \pm 29.96^{* *}\end{array}$ & $\begin{array}{l}866.44 \pm 42.74 \\
687.9 \pm 36.64 * *\end{array}$ & $\begin{array}{l}812.20 \pm 43.15 \\
585.43 \pm 28.96 * *\end{array}$ & $\begin{aligned} 755.30 & \pm 37.94 \\
. \quad 522.35 & \pm 29.52^{* *}\end{aligned}$ \\
\hline
\end{tabular}

$*=$ Results are means $\pm S E$.

$* *=$ Protein-deficient group is significantly different from control group at $\mathrm{p}<0.05$. 
Tab. 4. Effect of protein deficiency on the urinary excretion of free hydroxyproline ( $\mu \mathrm{mol} / \mathrm{g}$ creatinine) in the rat.

\begin{tabular}{|c|c|c|c|c|c|}
\hline \multirow[b]{2}{*}{ Group } & \multirow[b]{2}{*}{0} & \multirow[b]{2}{*}{7} & \multicolumn{2}{|l|}{ Days } & \multirow[b]{2}{*}{28} \\
\hline & & & 14 & 21 & \\
\hline $\begin{array}{l}\text { Control } \\
\text { Deficient }\end{array}$ & $\begin{array}{l}16.86 \pm 0.84^{*} \\
16.32 \pm 1.98\end{array}$ & $\begin{array}{l}14.72 \pm 0.69 \\
12.66 \pm 0.53^{* *}\end{array}$ & $\begin{array}{l}18.46 \pm 0.92 \\
16.63 \pm 0.69\end{array}$ & $\begin{array}{l}15.48 \pm 0.61 \\
12.51 \pm 0.53^{* *}\end{array}$ & $\begin{array}{l}16.32 \pm 0.69 \\
13.04 \pm 0.53^{* *}\end{array}$ \\
\hline
\end{tabular}

$*=$ Results are means $\pm \mathrm{SE}$.

** = Protein-deficient group is significantly different from control group at $p<0.05$.

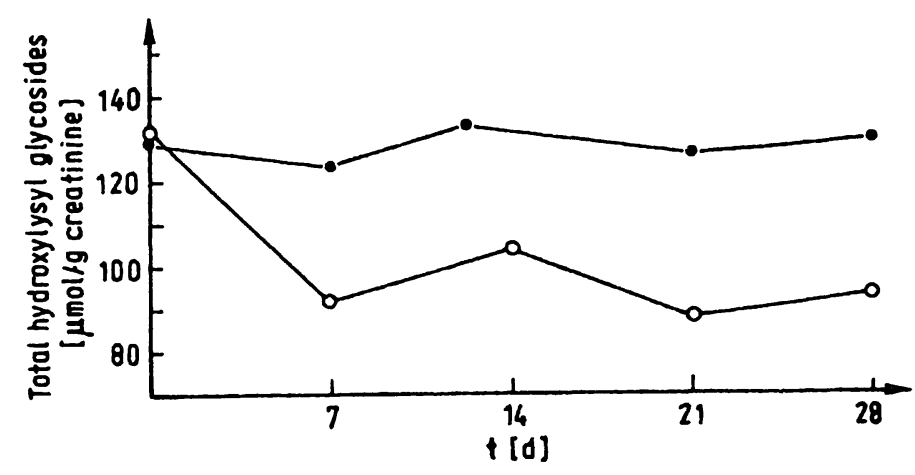

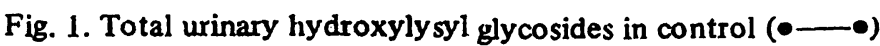
and protein-deficient rats $(0-0)$.

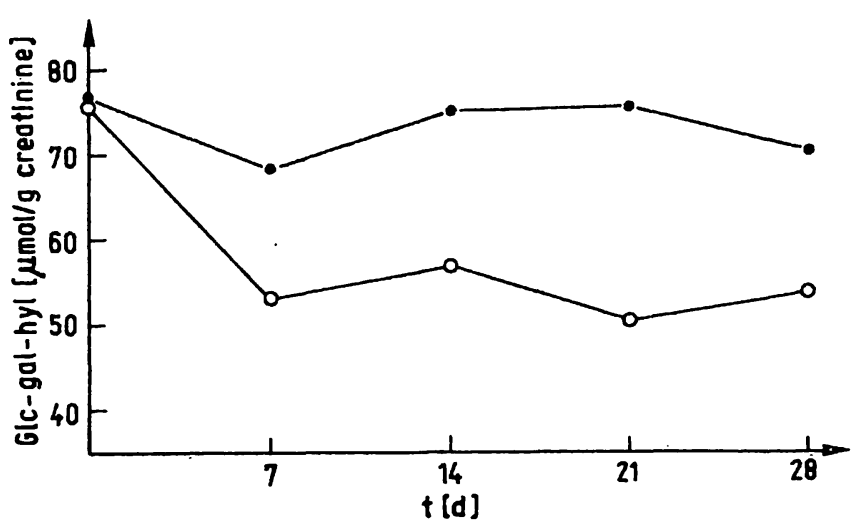

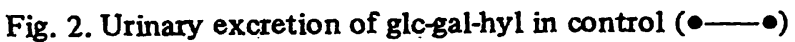
and protein-deficient rats $(0-0)$.

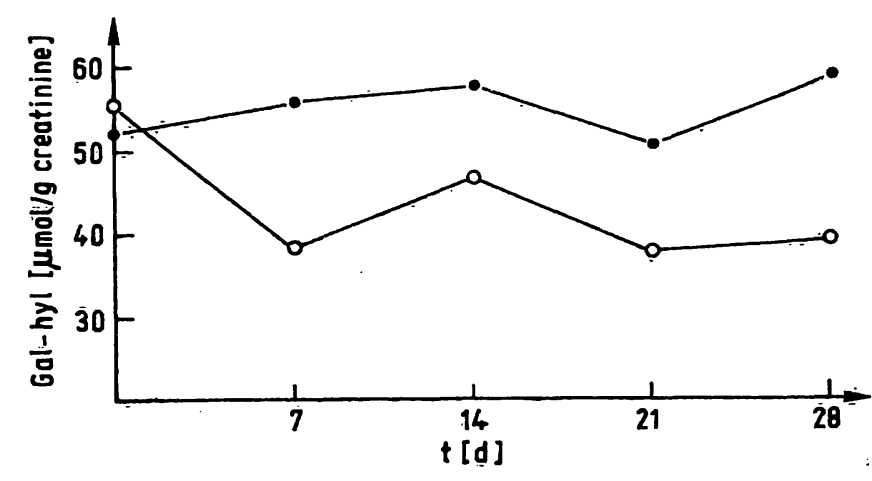

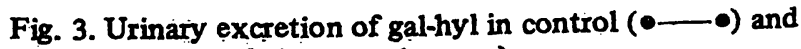
protein-deficient rats $(0 \div 0)$.

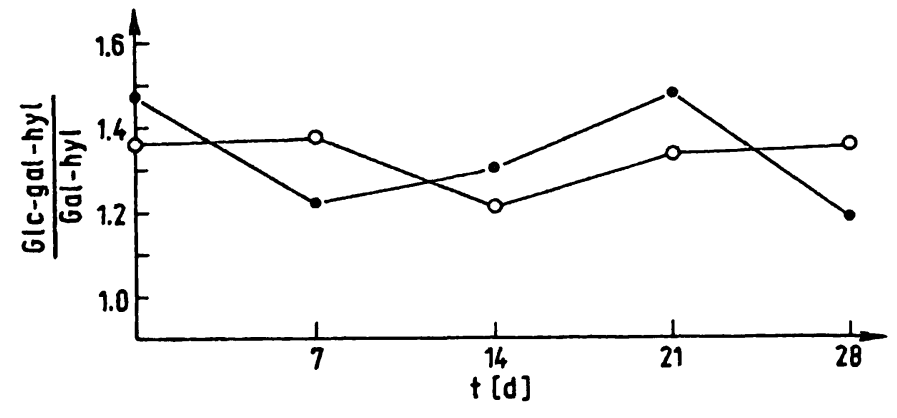

Fig. 4. Ratio of urinary glc-gal-hyl/gal-hyl in control (•-•) and protein-deficient rats $(0-0)$.

from the 14th day onwards. The excretion of both glcgal-hyl (fig. 2) and gal-hyl (fig. 3) were also decreased in protein malnutrition. As the excretion of both glycosides was more or less equally decreased in the protein deficient animals, the glc-gal-hyl/gal-hyl ratio (fig. 4) was comparable to that of normals.

\section{Discussion}

The unique distribution of hydroxyproline in collagen where it accounts for $13-14 \%$ of the total amino acids (21) makes it unlikely that any other component in the body could serve as a significant source of urinary hydroxyproline. Urinary excretion of hydroxyproline is proved to be a reliable index of collagen catabolism since the final breakdown products of collagen, which include both free and peptide bound hydroxyproline, are not reutilized for collagen biosynthesis $(11,22,23)$. Alterations in the urinary hydroxyproline have been shown (24) to be due to the changes in the rate of collagen synthesis, the rate of conversion of one form of collagen to another, or the rate at which any of the forms is degraded.

A marked decrease in the excretion of urinary hydroxyproline was observed in the protein deficient animals (tab. 1). Earlier studies indicated $(5,6,15)$ a decrease in the urinary hydroxyproline in rats due to the influence of protein malnutrition. Similar results have also been reported in children with protein malnutrition $(13,14,25,26)$. 
In human protein malnutrition, the urinary hydroxyproline levels are usually measured at a point where protein deficiency is fairly established. However, these studies do not indicate the stage at which hydroxyproline decreases considerably. Results of the present investigation (tab. 1) reveal that the decrease in the urinary hydroxyproline due to the influence of protein malnutrition is pronounced on 7 th day, and later the decrease is slow. It may therefore be concluded that protein deficiency exerts most of its effect on urinary hydroxyproline during the early phases of protein malnutrition.

The decreased excretion of urinary hydroxyproline in protein deficient animals may be due to either reduced body collagen content, reduced collagen synthesis or reduced catabolism of collagen. A marked loss of skin collagen is reported in both experimental and clinical cases of protein malnutrition $(5,6,27,28)$. The soluble collagen, which represents mainly newly synthesized collagen (29), is also found to be decreased in protein deficient animals and in Kwashiorkar $(5,7,30)$. Earlier studies in this laboratory indicated that the decreased rates of both synthesis and catabolism of collagen contributed to the decreased excretion of urinary hydroxyproline in protein deficient animals (10).

It has been demonstrated that the nondialysable hydroxyproline peptides in urine are derived either from collagen recently synthesized and rapidly degraded or from fragments recently synthesized but not incorporated into tropocollagen (31). Further studies have indicated (32) that appraisal of nondialysable and dialysable hydroxyproline in urine may contribute to an evaluation of the relative contribution of bone formation and resorption to total bone turnover. In the present study, the striking fall in nondialysable hydroxyproline (tab. 2) in protein deficient animals was accompanied by a proportional decrease of the dialysable fraction (tab. 3). These results may therefore suggest decreased turnover of bone collagen. Isotopic studies in this laboratory have also shown (33) that the turnover of bone collagen is decreased in protein deficient rats.

It has been reported (34) that about $80 \%$ of the total hydroxylysine in normal urine is associated with sugars in two glycosidic compounds glucosyl-galactosyl-hydroxylysine (glc-gal-hyl) and galactosyl-hydroxylysine (gal-hyl). Recent studies have indicated that the levels of urinary hydroxylysyl glycosides are better quantitative indicators of collagen metabolism than urinary hydroxyproline (34, 36). The urinary excretion of total hydroxylysyl glycosides seems to parallel the urinary hydroxyproline in all conditions associated with an alteration in the metabolism of collagen $(34,36,37)$. The results of the present study (fig. 1) also show that the excretion of total urinary hydroxylysyl glycosides parallels the urinary hydroxyproline in protein deficient animals.

As skin collagen contains twice as much glc-gal-hyl as gal-hyl, and bone contains seven times more gal-hyl than glc-gal-hyl, it is suggested $(34,35)$ that the ratio of glcgal-hyl to gal-hyl would indicate the proportion of collagen degradation derived from skin and bone. It has been shown (38) that only less than $10 \%$ of the glcgal-hyl excreted in urine could come from glomerular basement membrane and $\mathrm{C} 1 \mathrm{q}$ subcomponent of the complement system, which are known to contain high amounts of glc-gal-hyl. It may be concluded therefore that the main source of urinary hydroxylysyl glycosides is collagen of bone and skin. The normal ratio of glc-galhyl/gal-hyl found in protein deficient animals (fig. 4) clearly demonstrated that both bone and skin collagens have a similar decreased turnover compared to controls.

\section{Acknowledgements}

The authors are thankful to Dr. N. Ramanathan, Acting Director, Central Leather Research Institute, Madras, for his keen interest and permission to publish the results. The financial assistance to one of the authors (J.S.R.) by the Council of Scientific \& Industrial Research, New Delhi is gratefully acknowledged.

\section{References}

1. Stahl, S. S. (1963), Arch. Oral Biol. 7, 551-556.

2. Peacock, E. E. (1960), Proc. Soc. Exp. Biol. Med. 105, 380-383.

3. Sambasiva Rao, J. \& Rao, V. H. To be published.

4. Dickerson, J. W. T. \& John, P. M. V. (1969), Brit. J. Nutr. 23, 917-924.

5. Rao, V. H. \& Bose, S. M. (1969), cited in Biological Aspects of Leather Manufacture (Bhaskaran, R. Nandy, S.C. \& Krishnamurthi, V. S., eds.) C.L.R.I., Madras, pp. 161-170.

6. Anasuya, A. \& Rao, B. S. N. (1970), Brit. J. Nutr. 24, 97-107.

7. Mc Clain, P. E., Wiley, E. R. \& Beecher, G. R. (1975), Nutr. Rep. Int. 12, 317-324.

8. Angeleli, A. Y. O., Burini, R. C. \& Campana, A. S. (1978), J. Nutr. 108, 1147-1154.

9. Arumugham, R. \& Bose, S. M. (1979), Acta Biochem. Pol. (In press).
10. Sambasiva Rao, J. \& Rao, V. H. (1979), Ital. J. Biochem. (Under publication).

11. Kivirikko, K. I. (1970), Int. Rev. Conn. Tiss. Res. 5, 93-163.

12. Birkenhager, J. C. (1.970), Folia Med. Neerl. 13, 79-87.

13. Picou, D., Alleyne, G. A. O. \& Seakins, A. (1965), Clin. Sci. $29,517-523$.

14. Anasuya, A. \& Rao, B. S. N. (1966), Ind. J. Med. Res. 54, 849-857.

15. Widdowsin, E. M. \& Whitehead, R. G. (1966), Nature (London) 212, 683-686.

16. Rao, V. H. \& Bose, S. M. (1968), Leather Sci. 15, 33-39.

17. Rojkind, M. \& Gonzalez, E. (19.74), Anal. Biochem. 57, $1-7$.

18. Hadded, J. G., Couranz, S. \& Avioli, L. V. (1970), J. Clin. Endocrinol. 30, 282-287.

19. Askenasi, R. (1973), Biochim. Biophys. Acta 304, 375-383. 
20. Picou, D., Alleyne, G. A., Waterlow, J. C. \& Seakins, A. (1965), Biochem. J. 95, 18 p.

21. Neuman, R. E. \& Logan, M. A. (1950), J. Biol. Chem. 186, 549-556.

22. Prockop, D. J. \& Kivirikko, K. I. (1967), Ann. Intern. Med. $66,1243-1266$.

23. Laitinen, O. (1974), Acta. Med. Scand., Suppl. 577, 1-55.

24. Prockop, D. J. (1964), J. Clin. Invest. 43, 453-460.

25. Anasuya, A. \& Rao, B. S. N. (1966), Lancet $I, 94$.

26. Howells, G. R., Wharton, B. A. \& Mc Cance, R. A. (1967), Lancet $I, 1082-1083$.

27. Halliday, D. (1967), Clin. Sci. 33, 365-70.

28. Vasantha, L. (1970), Amer. J. Clin. Nutr. 23, 99-104.

29. Jackson, D. S. \& Bentley, J. P. (1960), J. Biophys. Biochem. Cytol. 7, 37-42.

30. Vasantha, L. (1969), Clin. Chim. Acta 26, 277-280.
31. Krane, S. M., Munoz, A. J. \& Harris, E. D. (1970), J. Clin. Invest. 49, 716-729.

32. Haddad, J. G., Couranz, S. \& Avioli, L. V. (1970), J. Clin. Endocrinol. 30, 282-287.

33. Sambasiva Rao, J. \& Rao, V. H. (1979), Leather Sci. (Under publication).

34. Segrest, J. P. \& Cunningham, L. W. (1970), J. Clin. Invest. 49, 1497-1509.

35. Pinnell, R. S., Fox, R. \& Krane, S., Biochim. Biophys. Acta 229, 119-122.

36. Askenasi, R. (1974), J. Lab. Clin. Med. 83, 673-679.

37. Lou, M. F. \& Hamilton, P. B. (1971), Clin. Chem. 17, 782-788.

38. Askenasi, R. (1978), Cited in Biology and Chemistry of Basement Membranes (Kefalides, N. A., ed.) Academic Press, New York pp. 443-451.

J. Sambasiva Rao

Department of Biochemistry Central Leather Research Institute Madras 600 020, India 
